\title{
The Anti-Biofouling Properties of Superhydrophobic Surfaces are Short-Lived
}

Gi Byoung Hwang ${ }^{\mathrm{a}}$, Kristopher Page ${ }^{\mathrm{a}}$, Adnan Patir ${ }^{\mathrm{a}}$, Sean P. Nair ${ }^{\mathrm{b}}$, Elaine Allan ${ }^{\mathrm{b}}$ and Ivan

$$
\text { P. Parkin }{ }^{a *}
$$

${ }^{a}$ Materials Chemistry Research Centre, Department of Chemistry, University College London, 20 Gordon Street, London, WC1H OAJ, United Kingdom

${ }^{b}$ Department of Microbial Diseases, UCL Eastman Dental Institute, University College London, 256 Gray's Inn Road, London WC1X 8LD, United Kingdom

Keyword: superhydrophobic surface, S. aureus, E. coli, anti-biofouling property, and plastron effect

* To whom correspondence should be addressed.

E-mail: i.p.parkin@ucl.ac.uk Tel: 44(0)207 6794669 


\section{ABSTRACT}

Superhydrophobic surfaces are present in nature on the leaves of many plant species. Water rolls on these surfaces and the rolling motion picks up particles including bacteria and viruses. Man-made superhydrophobic surfaces have been made in an effort to reduce biofouling. We show here that the anti-biofouling property of a superhydrophobic surface is due to an entrapped air-bubble layer that reduces contact between the bacteria and the surface. Further, we showed that prolonged immersion of superhydrophobic surfaces in water led to loss of the bubble-layer and subsequent bacterial adhesion that unexpectedly, exceeded that of the control materials. This behavior was not restricted to one particular type of material but was evident on different types of superhydrophobic surfaces. This work is important in that it suggests that superhydrophobic surfaces may actually encourage bacterial adhesion during longer term exposure. 
Bacterial biofilms on surfaces are known to produce adverse impacts in many situations such as pipeline corrosion, water contamination, and hospital associated infections. ${ }^{1-7}$ Intensive effort is focused on the design of antibacterial surfaces to limit bacterial attachment and subsequent biofilm formation. ${ }^{8-11}$ The use of superhydrophobic surfaces (SHS) is considered a promising anti-biofouling strategy because such surfaces have been reported to significantly reduce bacterial adhesion. ${ }^{12-14}$ Some variation in experimental design is evident in tests of superhydrophobic surfaces with some studies employing a continuous flow of bacterial suspension over the superhydrophobic surface whereas others have simply immersed the material in a static bacterial suspension for various periods of time. ${ }^{15-19}$ Crick et al. (2011) and Ozkan et al. (2016) demonstrated a $58-80 \%$ and $50-79 \%$ reduction in adhesion, respectively, of $S$. aureus and E. coli to a superhydrophobic surface produced by aerosol-assisted chemical vapor deposition (AACVD) compared with uncoated glass, and Privett et al. (2011) showed a $99 \%$ and $98 \%$ reduction in the adhesion of S. aureus and Pseudomonas aeruginosa, respectively, on silica-colloid-doped substrates, compared to the substrate without the colloid. ${ }^{15-16,19}$ Freshauf et al. (2012) showed that superhydrophobic polystyrene, polycarbonate, and polyethylene surfaces had low initial adhesion of E. coli and good removal efficiency: about $2 \%$ of the initial bacterial population attached to the superhydrophobic surfaces and after rinsing with PBS, only $0.1 \%$ cells of the attached cells remained on the surface. ${ }^{18}$ Previous studies suggested that the reduced adsorption of proteins on to superhydrophobic surfaces reduces bacterial adhesion, and enables easy detachment of bacteria. ${ }^{20-24}$

In this work, a previously described superhydrophobic surface was used. ${ }^{25}$ Our work shows that air bubbles are physically entrapped on a superhydrophobic surface when the material is immersed in a bacterial suspension. This results in a reduced contact area between the bacteria and the superhydrophobic surface, resulting in a significant reduction in the number of adherent bacteria following $1 \mathrm{~h}$ of exposure. However, the air-bubble layer was not maintained at the 
surface over a longer period of time. After $2.5 \mathrm{~h}$ immersion time, the air-bubble layer disappeared and after $24 \mathrm{~h}$ of exposure, bacterial adhesion on the superhydrophobic surface was more extensive than on smooth intact glass, polyurethane, or polystyrene surfaces, presumably due to the high surface roughness of the superhydrophobic material.

\section{RESULT AND DISCUSSION}

\section{Surface Roughness and Water Contact Angle of the Tested Samples}

As control materials, a glass slide (VWR, PA, USA), polyurethane (PU, American Polyfilm Inc, Branford, CT, USA), white polystyrene sheet A (WPSA, Station Road Baseboards, Norwich, UK) and white polystyrene sheet B (WPSB, Station Road Baseboards were used, and a robust superhydrophobic surface was produced using $1 \mathrm{H}, 1 \mathrm{H}, 2 \mathrm{H}, 2 \mathrm{H}-$ perfluorooctyltriethoxysilane, $\mathrm{P} 25 \mathrm{TiO}_{2}$ nanoparticles, ethanol, and double sided tape. ${ }^{25}$ The size $(2.5 \mathrm{~cm} \times 5.5 \mathrm{~cm})$ of all samples was the same. Before the bacterial attachment assay, the water contact angle and surface roughness of the samples were determined using a drop shape analyser (FTA 1000B, First Ten Angstroms, Inc., Portsmouth, Virginia, USA) and atomic-force microscopy (AFM, EasyScan 2 AFM, Nanosurf, Liestal, Switzerland), respectively. As shown in Table 1, Figure S1, and Video S1, the superhydrophobic surface showed a water contact angle of $>160^{\circ}$ with low rolling off angle $\left(0^{\circ}\right)$ and contact angle hysteresis $\left(0.4^{\circ}\right)$ and displayed good water-repellent property. The superhydrophobic surface had the highest water contact angle and surface roughness of all the samples tested whereas the lowest water contact angle $\left(5.7^{\circ}\right)$ and roughness $(4.9 \mathrm{~nm})$ was observed with glass (Table 1, Figure S1, and S2) (water contact angle: glass slide $<$ WPSB $<$ WPSA $<$ PU $<$ SHS; surface roughness: glass slide $<$ WPSA $<$ PU $<$ WPSB $<$ SHS).

\section{Bacterial Adhesion on the Samples after 1 h of Exposure}


In the bacterial attachment assay, the samples were immersed in bacterial suspensions $\left(\sim 10^{8}\right.$ $\mathrm{CFU} / \mathrm{mL}$ ) in either BHI broth or PBS and incubated for $1,4,8,16$, and $24 \mathrm{~h}$ at $37^{\circ} \mathrm{C}$. To quantitatively compare bacteria attached to the samples, equal sized samples with attached bacteria were stained by using $0.1 \%$ crystal violet $(\mathrm{CV})$ solution. After thorough washing to remove unbound $\mathrm{CV}$, the bound $\mathrm{CV}$ was solubilized in ethanol and the absorbance, proportional to the number of attached bacteria, was measured at a wavelength of $590 \mathrm{~nm} .{ }^{26-27}$ For this study, a methicillin-sensitive strain of Staphylococcus aureus (S. aureus 8325-4), Escherichia coli (E. coli ATCC 25922), a clinical strain of methicillin-resistant Staphylococcus aureus (MRSA 4742; obtained from P. Wilson, University College London Hospital), and a clinical strain of Escherichia coli which expresses a carbapenemase enzyme (CRE 1030; obtained from J. Wade, King's College London) were used. Before the bacterial adhesion test, samples including glass, polyurethane, polystyrenes which liquid does not penetrate, were chosen because liquid absorbing materials such as textile, and paper can absorb crystal violet molecules resulting in a production of wrong experimental result. it was confirmed that the superhydrophobic surface alone was not stained by $\mathrm{CV}^{25}$ and that $\mathrm{CV}$ staining of the other surfaces was negligible (optical density at $590 \mathrm{~nm}<0.01)$. As shown in Figure 1, the superhydrophobic surface showed less bacterial adhesion compared to the glass, WPSA, PU or WPSB after $1 \mathrm{~h}$ of exposure to a bacterial suspension in either BHI or PBS (Mann-Whitney $U$ test: $p$-value $<0.05$ for all bacterial species in either BHI or PBS). With S. aureus, MRSA, E. coli, and CRE in BHI, bacterial adhesion on the superhydrophobic surface was $26-91 \%$ lower compared to the other surfaces, and indeed the decrease in CRE attachment to the superhydrophobic surface was $\sim 91 \%$ compared to other surfaces. In PBS, bacterial attachment to the superhydrophobic surface was $35-82 \%$ lower compared to the other materials, and the most dramatic reduction in bacterial adhesion was observed for $S$. aureus $8325-4$ which adhered most readily to the control surfaces and showed a $69-82 \%$ reduction in adhesion to the superhydrophobic surface compared to 
glass, WPSA, PU, or WPSB.

\section{Bacterial Adhesion to the Superhydrophobic Surface with Increasing Exposure Time}

Figure 2 (a) and (b) show that bacterial adhesion to the superhydrophobic surface increased with exposure time. After $24 \mathrm{~h}$, the number of bacteria attached to the superhydrophobic surface increased 12-fold compared to the levels of adhesion at $1 \mathrm{~h}$ (as measured by CV staining) and the most significant increases in adhesion was apparent for CRE in BHI and S. aureus in PBS: the numbers of attached CRE and S. aureus after $24 \mathrm{~h}$ was 43 and 41 times higher, respectively, than at $1 \mathrm{~h}$. Figure 2 (c) and (d) show surface coverage of $S$. aureus, MRSA, E coli and CRE on the superhydrophobic surface with increasing exposure time. The photograph insets in Figures 2 (c) and (d) show the CV-stained materials after exposure to S. aureus. It was curious that colonization occurred usually from the edges of the superhydrophobic material and progressed uniformly across the entire surface. After $24 \mathrm{~h}$ of bacterial exposure, $95-99 \%$ and 93-99\% of the superhydrophobic surfaces were colonized by bacteria in BHI and PBS, respectively.

\section{Change of the Water Contact Angle on Superhydrophobic Surface with Increasing Time of Exposure to Bacteria}

Figure 3 (a) shows the average water contact angle of the superhydrophobic surface in terms of the exposure time to bacteria. Before the experiment, it was confirmed that neither sterile PBS nor BHI affected the water repellency of the superhydrophobic surface over the course of $24 \mathrm{~h}$. At time zero the superhydrophobic surface gave a water contact angle of $>150^{\circ}$ in both PBS and BHI. After $24 \mathrm{~h}$ of bacterial exposure in BHI and PBS, the average contact angle of the superhydrophobic surfaces exposed to different bacteria ranged from 111.9 to $96.4^{\circ}$, indicating that the superhydrophobic surface had become hydrophobic. Figure 3 (b) shows the 
progressive reduction in the water contact angle across the superhydrophobic surface with increasing time of exposure to bacteria. It was observed that after $1 \mathrm{~h}$ of exposure to bacteria, the majority of the surface had a water contact angle of $>150^{\circ}$ although an edge of superhydrophobic surface had a small contact angle reduction. However, after $4 \mathrm{~h}$ of the exposure, a dramatic reduction (reduction angle: 50-60 ${ }^{\circ}$ ) of water contact angle on the edge was observed and this area diffused across the superhydrophobic surface with increasing exposure time and the reduction was confirmed across the superhydrophobic surface after 24 $\mathrm{h}$ of bacterial exposure. This is explained by the fact that the adhesion of bacteria, which have a hydrophilic surface (Figure S3) causes a reduction in water contact angle of the superhydrophobic surface. As shown Figure S4 and S5, SEM and confocal microscopy showed that after the $24 \mathrm{~h}$ exposure, bacteria attached to the superhydrophobic surface. AFM analysis showed that due to bacterial adhesion, the roughness of the superhydrophobic surface decreased from 853.7 to $501.8 \mathrm{~nm}$.

\section{Bacterial Adhesion after $24 \mathrm{~h}$ of Exposure}

Figure 4 (a) and (b) show a comparison of bacterial attachment to a glass slide, WPSA, PU, WPSB, and the superhydrophobic surface after $24 \mathrm{~h}$ exposure in either BHI or PBS. In contrast with a $1 \mathrm{~h}$ exposure in which the superhydrophobic surface showed reduced adhesion compared to the control (Figure 1), at $24 \mathrm{~h}$ the number of bacteria attached to the superhydrophobic surface was greater $(>1.6$ times, Mann-Whitney $U$ test: $p$-value $<0.01)$ than that attached to either the glass slide, WPSA, PU, or WPSB in both BHI and PBS. Compared to glass, there was a 9-fold or 11-fold increase in the density of adherent bacteria to the superhydrophobic surface at $24 \mathrm{~h}$ for CRE (in BHI) and MRSA (in PBS), respectively. To determine if the increased adhesion at $24 \mathrm{~h}$ was specific for this particular superhydrophobic surface, the experiment was repeated with other superhydrophobic surfaces which are chemically different, 
and the results were similar (Supporting information Figure S6 and 7).

To determine the factors that contribute to the large increase in bacterial adhesion on superhydrophobic surfaces after prolonged exposure, the materials were analysed in terms of surface roughness, and water contact angle. ${ }^{28-31}$ As shown in Figure 4 (c) and (d), there was a statistically significant correlation between the number of attached bacteria and the surface roughness of the material (Pearson correlation coefficient (PCC): $0.94<\mathrm{r}<1$ for all bacteria in BHI and PBS). However, there was no relationship between the water contact angle of the sample and the number of attached bacteria (Figure S8). In previous research, superhydrophobic surfaces, which are in the Cassie-Baxter slippery state, have been reported to have less bacterial adhesion than glass, and hydrophobic or hydrophilic surfaces, and it was speculated that when the superhydrophobic surface resulting from a rough surface with low surface energy is immersed in bacterial suspension, air-bubbles are entrapped on the surface, resulting in decreased bacterial adhesion. ${ }^{16,26}$ However, this present study showed that over a longer period of time, bacterial adhesion on a superhydrophobic surface is more extensive than on the other surfaces and this is due to the high roughness of the superhydrophobic surfaces. This was confirmed with chemically different superhydrophobic surfaces (PCC: $0.95<\mathrm{r}<0.99$ at MRSA in BHI and PBS).

\section{The Air Bubble Layer Prevents $S$. aureus from Recognizing the Surface}

When bacteria associate with a surface, they are thought to recognize the adhesion force exerted by the surface and respond by producing adhesive molecules which increase the strength of the interaction. It has been shown that the adhesion forces cause nanoscale deformation of the bacterial cell wall and this is thought to be detected by mechanicallysensitive receptors in the cell membrane. ${ }^{32-33}$ Previous work has shown that a $S$. aureus pbp4 mutant, which has defective cell wall structure (reduced frequency of cross-linked 
peptidoglycan) exhibits increased cell wall deformation on interaction with a surface and a reduced adhesion force indicating that normal peptidoglycan structure is crucial for proper surface recognition. ${ }^{33}$ In this work, we hypothesized that the air bubble layer was effectively 'cushioning' the surface and preventing the bacteria from recognizing the surface adhesion force. To test this, we investigated adhesion of a $S$. aureus pbp 4 mutant to the superhydrophobic surface in comparison with the isogenic wild-type strain. Figure 5 (a) shows that, while there was no difference in the ability of the two strains to colonise the material at $1 \mathrm{~h}$ (both strains colonized poorly) after $24 \mathrm{~h}$ the pbp4 mutant colonised significantly less well compared to the parent strain. This suggests that the air bubble layer present initially on the superhydrophobic surface masks the adhesion force thus preventing the bacterium from recognizing the surface. Once the air bubble layer is lost, however, the force exerted by the surface is detectable by the bacterium but only if it has normal peptidoglycan structure. (t-test: $p$-value $<0.05$ at BHI and $p$-value $<0.01$ at PBS). This data agrees with previous work in that the $p b p 4$ mutant is defective in surface sensing. ${ }^{33}$ Further, it shows that the anti-adhesion activity of the superhydrophobic surface is due to a short-term 'cushioning' effect of the trapped air bubble layer which prevents bacterial detection of the force exerted by the surface.

\section{Detection of the Air-Bubble Layer on Superhydrophobic Surface by the Plastron Effect.}

When the superhydrophobic surface, in a Cassie-Baxter state (slippery to water), is immersed in water and rotated about 49 degree (glancing angle), a mirror like surface appears because of light reflection. ${ }^{34-35}$ It was reported that this effect is due to an air-bubble layer between the water and the superhydrophobic surface which is known as a plastron effect. ${ }^{34,36}$ Figure 5 (b) shows the mirror-like surface generated as a result of the plastron effect of the superhydrophobic surface. The mirror like surface appeared right after the material was immersed in water and the effect was present with all the superhydrophobic surfaces tested. 
However, after $60 \mathrm{~min}$, the mirror like surface started to disappear and it was obvious only around the edge of the superhydrophobic surfaces after $120 \mathrm{~min}$, before it disappeared completely after $150 \mathrm{~min}$, indicating loss of the air-bubble layer between the water and the superhydrophobic surface. The pattern of air-bubble loss on the superhydrophobic surface was similar to the pattern of the bacterial colonization of the surface and the reduction of water contact angle on the surface (Figure S9). Here the pattern of bacterial adhesion on the superhydrophobic surface correlates with the pattern of air-bubble loss. Thus, it appears that the presence of air bubbles prevents bacterial adhesion (Figure S10).

Figure 5 (c) shows the shape of the air-bubble layer entrapped on the superhydrophobic surface. Because the size of air-bubble layer on the superhydrophobic surface with a surface roughness of approximately $1 \mu \mathrm{m}$ was too fine, it was not possible to detect the layer on the surface immersed in water using optical microscopy. Thus, to confirm the bubble layer, a superhydrophobic surface with a surface roughness of about $139.5 \mu \mathrm{m}\left(\mathrm{R}_{\mathrm{a}}\right)$ was produced. The surface was immersed in water and it was photographed side on using optical microscopy. Right after its immersion in water, it was clearly observed that air-bubbles were entrapped between humps of the superhydrophobic surface. This clearly explains how the superhydrophobic surface has less adhesion than other surfaces over such a short period of time. The bubble layer reduced the contact area between the bacteria and the superhydrophobic surfaces and the air/water interface was not penetrated by the bacteria. ${ }^{16}$ However, the thickness of the air-bubble layer decreased with immersion time because air dissolved into the water. ${ }^{36-}$ ${ }^{39}$ The air bubble layer vanished at the surface after $60 \mathrm{~min}$. This shows why the bacterial adhesion on the superhydrophobic surface significantly increased with increasing the exposure time. As the air-bubble layer vanished, the high roughness $\left(\mathrm{R}_{\mathrm{a}}: 853.7 \mathrm{~nm}\right)$ of the superhydrophobic surface offers a favourable environment for bacterial colonization (E. coli: $\sim 500 \mathrm{~nm}$ in diameter and $<2000 \mathrm{~nm}$ in length, and $S$. aureus: $<1000 \mathrm{~nm}$ in diameter) ${ }^{40-41}$ 
To determine the ease with which adhered bacteria could be removed from the various surfaces by cleaning, the materials were repeatedly and vigorously wiped with a gloved finger. As shown in Figure S11, bacteria were least efficiently removed from the superhydrophobic surface. This is presumably because bacteria were lodged in the grooves of the rough surface and were protected from the wiping motion.

With respect to the anti-biofouling mechanism of a superhydrophobic surface, previous work showed that a superhydrophobic surface was selective in that it prevented colonization by $P$. aeruginosa but not $S$. aureus and the authors proposed that this was due to the degree of surface contact made by the morphologically different bacteria. ${ }^{42-43}$ Other published studies present contrasting results, however, suggesting that superhydrophobic surfaces are effective in preventing colonization by $S$. aureus although the anti-biofouling mechanism is unknown and several theories were proposed. ${ }^{16,21,24,44}$

This study is to show that superhydrophobic surfaces have only a short-term anti-biofouling activity when exposed to a bacterial suspension and indeed show an increased propensity for bacterial colonization compared to control materials after prolonged exposure as a result of their surface roughness. The air-bubble layer entrapped on a superhydrophobic surface appears to have two actions: firstly, it reduces the area of contact between a bacterium and the surface and secondly, it may cushion the bacterium from the adhesion force exerted by the surface effectively rendering the surface undetectable by the bacteria. These actions are short-lived however, as the air bubbles dissolve in water ${ }^{45}$ and the high roughness of superhydrophobic surface becomes a favourable environment for bacterial colonisation. As a result, the number of bacteria attached to the superhydrophobic surface was significantly higher after $24 \mathrm{~h}$ than other substrates including glass, polystyrene, and polyurethane, and, it was more difficult to remove the bacteria by wiping. 


\section{CONCLUSION}

Many previous studies which report the anti-biofouling property of superhydrophobic surfaces have only investigated bacterial adhesion over short time periods $(<4 \mathrm{~h}) .{ }^{15-17,19} \mathrm{We}$ have shown that the anti-adhesion activity of superhydrophobic surfaces is short-lived and that their rough nature may actually enhance bacterial colonization over the longer term. This is important, since rather than reducing bacterial colonization, superhydrophobic surfaces may actually function as bacterial reservoirs which has important implications for their use in healthcare or food-preparation environments. This study corrects a misunderstanding on antibiofouling property of superhydrophobic surface at least under full immersion and it offers useful and valuable information for further development of antimicrobial surfaces. 


\section{METHODS}

\section{Sample Preparation}

Superhydrophobic surface (SHS): $1.0 \mathrm{~g}$ of 1H, 1H, 2H, 2H-perfluorooctyltriethoxysilane (PFOTES, $\mathrm{C}_{8} \mathrm{~F}_{13} \mathrm{H}_{4} \mathrm{Si}\left(\mathrm{OCH}_{2} \mathrm{CH}_{3}\right)_{3}$, Sigma-Aldrich, St. Louis, MO, UK) were mixed with 99.0 g of pure ethanol (EDM Millipore Co., Billerica, MA, UK), and then agitated for 5 min. $4 \mathrm{mg}$ of $\mathrm{P} 25 \mathrm{TiO}_{2}$ nanoparticles were dispersed in $40 \mathrm{~mL}$ of the mixture and sonicated for $1 \mathrm{~min}$. To produce robust superhydrophobic surfaces, double sided Sellotape (Henkel AG \& Company, KGaA, Düsseldorf, Germany) was attached to a slide glass, it was dipped in the mixture, and then the material was stored in the dark for $24 \mathrm{~h}$ before use.

Polyurethane (American Polyfilm Inc, Branford, CT, USA), and glass (VWR, PA, UK), white polystyrene sheet A (WPSA, Station Road Baseboards, Norwich, UK) and B (WPSB, Station Road Baseboards, Norwich, UK) were purchased and cut to the same size $(2.5 \mathrm{~cm} \times$ $5.5 \mathrm{~cm})$.

\section{Preparation of Bacterial Suspensions}

Staphylococcus aureus (S. aureus 8325-4), Escherichia coli (E. coli ATCC 25922), methicillin-resistant Staphylococcus aureus (MRSA 4742), and a multidrug resistant, carbapenemase-producing clinical strain of Escherichia coli (CRE 1030) were used for this study. S. aureus, E. coli, MRSA, and CRE were stored at $-70^{\circ} \mathrm{C}$ in brain-heart-infusion broth (BHI broth, Oxoid Ltd., Hampshire, England, UK) with 20\% (v/v) glycerol. E. coli and CRE were propagated on MacConkey agar (Oxoid Ltd., Hampshire, England, UK), and S. aureus and MRSA were propagated on mannitol salt agar (Oxoid Ltd.) $10 \mathrm{~mL}$ of BHI broth was inoculated with one bacterial colony and incubated at $37^{\circ} \mathrm{C}$ in air with shaking at $200 \mathrm{rpm}$.

\section{Bacterial Adhesion to Samples}

Bacteria in BHI broth: after $18 \mathrm{~h}$ incubation, the bacterial suspension was diluted 10 -fold to $\sim 10^{8}$ colony forming units per milliliter $(\mathrm{CFU} / \mathrm{mL})$ using $\mathrm{BHI}$ broth. 
Bacteria in phosphate buffered saline (PBS): After incubation for $18 \mathrm{~h}$, the bacteria were harvested by centrifugation at $5000 \mathrm{rpm}$ for $10 \mathrm{~min}$, washed using $10 \mathrm{~mL}$ of PBS, and centrifuged again to recover the bacteria which were re-suspended in $10 \mathrm{~mL}$ of PBS. The washed suspension was diluted 10 -fold to obtain $\sim 10^{8} \mathrm{CFU} / \mathrm{mL}$.

The glass slide, WPSA, WPSB, PU, and superhydrophobic surfaces were immersed in the bacterial suspensions and incubated at $37^{\circ} \mathrm{C}$ for $1,4,8,16$, and $24 \mathrm{~h}$. The samples were removed from the bacterial suspensions, washed in distilled (DI) water to remove non-/weakly adherent bacteria and placed into $0.1 \%$ crystal violet $(\mathrm{CV})$ solution for $15 \mathrm{~min}$ to stain the bacteria. The stained samples were vigorously washed in DI water twice, placed in $10 \mathrm{ml}$ of pure ethanol, and then vortexed for $5 \mathrm{~min}$ to solubilise the CV. Particulate debris was removed by centrifugation at $14,500 \mathrm{rpm}$ for $2 \mathrm{~min}$, and the absorption of the solution at $590 \mathrm{~nm}$ was measured using a UV-vis spectrometer.

\section{Bacterial Surface Coverage Measurement}

Following exposure to the bacterial suspensions, the samples were placed in CV solution to stain bacteria, then washed in DI water twice, and dried in the dark for $24 \mathrm{~h}$. The extent of coverage of stained bacteria on the samples was determined using ImageJ software (http://imagej.nih.gov/ij/): Colour threshold via image adjust was chosen and then hue, saturation and brightness of the sample image was controlled to select bacteria covered area which is stained by crystal violet. After that, the covered area was measured through analysis

Bacteria coverage was calculated as below

$$
\text { bacteria surface coverage }(\%)=100 \times \frac{\text { bacteia coverage area }}{\text { total area }}
$$

\section{Confocal Microscopy}


SYTO 9 green fluorescent nucleic acid stain in Live/Dead BacLightTM Bacterial Viability kit (L707; Invitrogen, Carlsbad, CA, USA) was used to confirm the bacteria attached to the surface of samples. SYTO 9 generally labels all bacteria. The excitation/emission wavelength of the stain are $485 / 530 \mathrm{~nm} .1 .5 \mu \mathrm{L}$ of SYTO 9 was mixed with $1 \mathrm{~mL}$ of PBS, and the solution was inoculated on the bacteria attached samples, and kept in the dark at room temperature for 15 min. The bacteria were visualized using confocal layer scanning microscopy (Bio-Rad Laboratories, Inc., Hercules, CA, USA).

\section{SEM and AFM Analyses}

The samples were coated by gold nanoparticles to inhibit charging. Scanning Electron Microscopy (SEM, JEOL Inc., Peabody, MA, USA) was used at an accelerating voltage of 5 $\mathrm{kV}$. Images were captured using SEMAfore software. Atomic force microscopy (AFM, EeasyScan 2 AFM, Nanosurf, Liestal, Switzerland) was used to investigate a roughness of the sample surfaces $(50 \mu \mathrm{m} \times 50 \mu \mathrm{m})$. For the tapping mode, both the NCLR mode and dynamic force mode was employed, and the resonant frequent of the cantilever ranged from 150 to 200 $\mathrm{kHz}$.

\section{Water Contact Angle}

The water contact angle on the samples was measured by a contact angle meter (First Ten Angstroms, Inc., Portsmouth, Virginia, USA). A droplet $(\sim 5 \mu \mathrm{L})$ of DI water was put onto the sample surface, photographed side on and the images were analyzed by Surftens 4.5 software. The contact angle hysteresis (CAH) was investigated by the "add and remove volume" method. ${ }^{46} \mathrm{CAH}$ was calculated by the variation of advanced angle and receding angle.

\section{Measurement of Water Contact Angle cross Superhydrophobic Surface}

To determine if the superhydrophobic surfaces kept their properties after bacterial exposure, the measurement of water contact angle was conducted. As shown in Figure S12, the angles across the superhydrophobic surface were determined after $1,4,8,16$, and $24 \mathrm{~h}$ bacteria 
exposures.

\section{Plastron Effect of Air Bubbles on Superhydrophobic Surface.}

The superhydrophobic surface was vertically immersed in DI water and rotated about 49 degree resulting in that the surface appearance changing from a white surface into mirror-like surface. Images of the surface were taken at intervals of 5 min.

\section{Air-Bubble Layer on Superhydrphobic Surface}

To confirm the air-bubble layer on the superhydrophobic surface, the uniformly structured surface was coated by superhydrophobic paint. The surface was immersed in DI water and it was photographed side on at intervals of $20 \mathrm{~min}$.

\section{Mutant Bacteria Test}

S. aureus (USA300 JE2, methicillin-resistance $S$. aureus (MRSA)) and $S$. aureus pbp4 (transposon mutant NE679, derived from JE2 strain) were used. ${ }^{47,48}$ BHI and PBS bacteria suspensions were prepared. The number of the bacteria is $\sim 10^{8}$ colony forming units per milliliter $(\mathrm{CFU} / \mathrm{mL})$. The superhydrophobic surface was placed in the bacterial suspension for 1 and $24 \mathrm{~h}$ at $37^{\circ} \mathrm{C}$. The sample was collected from the bacteria suspension, washed using DI water, and then placed into $0.1 \%$ crystal violet solution for $15 \mathrm{~min}$. The stained sample was vigorously washed using DI water twice, placed in $10 \mathrm{ml}$ of pure ethanol, and then vortexed for $5 \mathrm{~min}$ to transfer the crystal violet molecules from the sample to ethanol. After that, the solution was centrifuged at 14,500 rpm for 2 min and the absorption of the solution was measured at $590 \mathrm{~nm}$ using a UV-vis spectrometer.

\section{Measurement of Remaining Bacteria on Sample Surface after Finger Wiping}

Samples were immersed in bacterial suspension and incubated for $24 \mathrm{~h}$ at $37^{\circ} \mathrm{C}$, washed using DI water and then dried in the dark for $3 \mathrm{~h}$. To determine how many bacteria remained on the samples after cleaning, finger wiping was performed across the surface of the samples. 
As shown in Figure S13, a glove-wearing finger contacted the surface, moved forth and back for $5.5 \mathrm{~cm}$ and then sample was washed using DI water. Wiping was repeated three times on each sample. After that, they were placed in $0.1 \%$ crystal violet solution for $15 \mathrm{~min}$, washed by DI water twice, and then placed in $10 \mathrm{ml}$ of ethanol solution. The solutions were vortexed for $5 \mathrm{~min}$ and then spun at 14,500 rpm for $2 \mathrm{~min}$. The absorption of the CV solutions was measured at $590 \mathrm{~nm}$

\section{Statistical Analyses}

T-test, Mann-Whitney $U$ test, Pearson correlation coefficient on experimental data were analysed using SPSS (IBM Corporation, Armonk, New York, USA).

\section{ASSOCIATED CONTENT}

\section{Supporing Information}

\section{Supporting Figures}

Water contact angle and topography image of samples, water contact angle of bacterial conlonies, SEM, topography, and conforcal images of superhydrophobic surface, characterzations of superhydrophobic surfaces A adnd B, correlation between the number of bacteria and water contact angle on samples, plastron disappearance, bacterial colonization, and water contact angle reduction on superhydrophobic surface, relationship of bacteria adhesion and airbubble disapearance, bactrial quantity on samples before and after figner wiping, and experimental method.

\section{Supporting Video}

Water reppelency of superhydrophobic surface.

\section{AUTHOR INFORMATION}

\section{Corresponding Author}

E-mail: i.p.parkin@ucl.ac.uk

ORCID

Ivan P. Parkin: 0000-0002-4072-6610

\section{Author Contributions}


G. B. H. designed, performed the experiment, wrote and revised the manuscript, E. A. and I. P. P. designed, supervised the experiment, and revised the manuscript, K. P. and A. P. provided superhydrophobic surfaces and revised the manuscript, S.P N provided bacteria and mutants, interpreted data and revised the manuscript.

\section{ACLNOWLEGEMENT}

EPSRC is thanked for funding (EP/GO36675/1, EP/N510051/1, and EP/LO15862/1). $S$. aureus (strain JE2) and S. aureus pbp4 (transposon mutant NE679) were provided by the Network on Antimicrobial Resistance in Staphylococcus aureus (NARSA) for distribution by BEI Resources, NIAID, NIH: Nebraska Transposon Mutant Library (NTML) Screening Array, NR-48501 


\section{REFERENCES}

(1) Chesnokova, M. G.; Shalaj, V. V.; Kraus, J. A.; Mironov, A. J. Assessment of Soil Biocorrosion Severeness on the Pipeline Locations. Procedia Eng. 2015, 113, 57-61.

(2) Liu, F.; Yang, W.; Zhong, H.; Lu, J.; Zhao, C. Biofilm Growth Characteristics at Different Diesel Leakage Concentration. IJESD 2013, 111-115.

(3) Islander, R. L.; Devinny, J. S.; Mansfeld, F.; Postyn, A.; Shih, H. Microbial Ecology of Crown Corrosion in Sewers. J. Environ. Eng. 1991, 117, 751-770.

(4) Mahapatra, A.; Padhi, N.; Mahapatra, D.; Bhatt, M.; Sahoo, D.; Jena, S.; Dash, D.; Chayani, N. Study of Biofilm in Bacteria from Water Pipelines. J. Clin. Diagn. Res. 2015, 9, DC09-11.

(5) Boyce, J. M. Environmental Contamination Makes an Important Contribution to Hospital Infection. J. Hosp. Infect. 2007, 65, 50-54.

(6) Bagihalli, G. B.; Avaji, P. G.; Patil, S. A.; Badami, P. S. Synthesis, Spectral Characterization, in Vitro Antibacterial, Antifungal and Cytotoxic Activities of $\mathrm{Co}(\mathrm{II}), \mathrm{Ni}(\mathrm{II})$ and $\mathrm{Cu}(\mathrm{II})$ Complexes with 1,2,4-Triazole Schiff Bases. Eur. J. Med. Chem. 2008, 43, 2639-2649.

(7) Ayliffe, G. A. J.; Collins, B. J.; Lowbury, E. J. L.; Babb, J. R.; Lilly, H. A. Ward Floors and Other Surfaces as Reservoirs of Hospital Infection. J Hyg-Camb 1967, 65, 515-536.

(8) Hasan, J.; Crawford, R. J.; Ivanova, E. P. Antibacterial Surfaces: the Quest for a New Generation of Biomaterials. Trends Biotechnol. 2013, 31, 295-304.

(9) Sehmi, S. K.; Noimark, S.; Bear, J. C.; Peveler, W. J.; Bovis, M.; Allan, E.; MacRobert, A. J.; Parkin, I. P. Lethal Photosensitisation of Staphylococcus aureus and Escherichia coli Using Crystal Violet and Zinc OxideEncapsulated Polyurethane. J. Mater. Chem. B 2015, 3, 6490-6500.

(10) Hassan, I. A.; Parkin, I. P.; Nair, S. P.; Carmalt, C. J. Antimicrobial Activity of Copper and Copper(I) Oxide Thin Films Deposited via Aerosol-Assisted CVD. J. Mater. Chem. B 2014, 2, 2855-2860.

(11) Hwang, G. B.; Allan, E.; Parkin, I. P. White Light-Activated Antimicrobial Paint Using Crystal Violet. ACS Appl. Mater. Interfaces 2016, 8, 15033-15039.

(12) Mahalakshmi, P. V.; Vanithakumari, S. C.; Gopal, J.; Mudali, U. K.; Raj, B. Enhancing Corrosion and Biofouling Resistance Through Superhydrophobic Surface Modification. Curr. Sci. 2011, 101, 1328-1336.

(13) Shateri Khalil-Abad, M.; Yazdanshenas, M. E. Superhydrophobic Antibacterial Cotton Textiles. J. Colloid Interface Sci. 2010, 351, 293-298.

(14) Chung, J. S.; Kim, B. G.; Shim, S.; Kim, S. E.; Sohn, E. H.; Yoon, J.; Lee, J. C. Silver-Perfluorodecanethiolate Complexes Having Superhydrophobic, Antifouling, Antibacterial Properties. J. Colloid Interface Sci. 2012, 366, 64-69.

(15) Privett, B. J.; Youn, J.; Hong, S. A.; Lee, J.; Han, J.; Shin, J. H.; Schoenfisch, M. H. Antibacterial Fluorinated Silica Colloid Superhydrophobic Surfaces. Langmuir 2011, 27, 9597-9601.

(16) Crick, C. R.; Ismail, S.; Pratten, J.; Parkin, I. P. An Investigation into Bacterial Attachment to an Elastomeric Superhydrophobic Surface Prepared via Aerosol Assisted Deposition. Thin Solid Films 2011, 519 (11), 3722-3727.

(17) Tang, P. F.; Zhang, W.; Wang, Y.; Zhang, B. X.; Wang, H.; Lin, C. J.; Zhang, L. H. Effect of Superhydrophobic Surface of Titanium on Staphylococcus aureus Adhesion. J. Nanomater. 2011. ID178921, 8.

(18) Freschauf, L. R.; McLane, J.; Sharma, H.; Khine, M. Shrink-Induced Superhydrophobic and Antibacterial Surfaces in Consumer Plastics. PLoS One 2012, 7, e40987.

(19) Ozkan, E.; Crick, C. C.; Taylor, A.; Allan, E.; Parkin, I. P. Copper-Based Water Repellent and Antibacterial Coatings by Aerosol Assisted Chemical Vapour Deposition. Chem. Sci. 2016, 7, 5126-5131.

(20) Banerjee, I.; Pangule, R. C.; Kane, R. S., Antifouling Coatings: Recent Developments in the Design of Surfaces that Prevent Fouling by Proteins, Bacteria, and Marine Organisms. Adv. Mater 2011, 23, 690-718.

(21) Stallard, C. P.; McDonnell, K. A.; Onayemi, O. D.; O'Gara, J. P.; Dowling, D. P. Evaluation of Protein Adsorption on Atmospheric Plasma Deposited Coatings Exhibiting Superhydrophilic to Superhydrophobic Properties. Biointerphases 2012, 7, 31.

(22) Roach, P.; Shirtcliffe, N. J.; Farrar, D.; Perry, C. C. Quantification of Surface-Bound Proteins by Fluorometric Assay: Comparison with Quartz Crystal Microbalance and Amido Black Assay. J. Phys. Chem. B 2006, 110, 
20572-20579.

(23) Koc, Y.; de Mello, A. J.; McHale, G.; Newton, M. I.; Roach, P.; Shirtcliffe, N. J. Nano-Scale Superhydrophobicity: Suppression of Protein Adsorption and Promotion of Flow-Induced Detachment. Lab Chip 2008, 8, 582-6.

(24) Pernites, R. B.; Santos, C. M.; Maldonado, M.; Ponnapati, R. R.; Rodrigues, D. F.; Advincula, R. C. Tunable Protein and Bacterial Cell Adsorption on Colloidally Templated Superhydrophobic Polythiophene Films. Chem. Mater. 2012, 24, 870-880.

(25) Lu, Y.; Sathasivam, S.; Song, J.; Crick, C. R.; Carmalt, C. J.; Parkin, I. P. Repellent Materials. Robust SelfCleaning Surfaces that Function when Exposed to Either Air or Oil. Science 2015, 347, 1132-1135.

(26) Epstein, A. K.; Wong, T. S.; Belisle, R. A.; Boggs, E. M.; Aizenberg, J. Liquid-Infused Structured Surfaces with Exceptional Anti-Biofouling Performance. PNAS 2012, 109, 13182-13187.

(27) O'Toole, G. A.; Kolter, R. Initiation of Biofilm Formation in Pseudomonas fluorescens WCS365 Proceeds via Multiple, Convergent Signalling Pathways: a Genetic Analysis. Mol. Microbiol. 1998, 28, 449-461.

(28) Feng, G.; Cheng, Y.; Wang, S. Y.; Borca-Tasciuc, D. A.; Worobo, R. W.; Moraru, C. I. Bacterial Attachment and Biofilm Formation on Surfaces are Reduced by Small-Diameter Nanoscale Pores: How Small is Small Enough? NPJ Biofilms Microbiomes 2015, 1, 15022.

(29) Ammar, Y.; Swailes, D.; Bridgens, B.; Chen, J. Influence of Surface Roughness on the Initial Formation of Biofilm. Surf. Coat. Technol. 2015, 284, 410-416.

(30) Cerca, N.; Pier, G. B.; Vilanova, M.; Oliveira, R.; Azeredo, J. Quantitative Analysis of Adhesion and Biofilm Formation on Hydrophilic and Hydrophobic Surfaces of Clinical Isolates of Staphylococcus epidermidis. Res. Microbiol. 2005, 156, 506-514.

(31) Pringle, J. H.; Fletcher, M. Influence of Substratum Wettability on Attachment of Freshwater Bacteria to Solid Surfaces. Appl. Environ. Microbiol. 1983, 45, 811-817.

(32) Harapanahalli, A. K.; Younes, J. A.; Allan, E.; van der Mei, H. C.; Busscher, H. J. Chemical Signals and Mechanosensing in Bacterial Responses to Their Environment. PLoS Pathog 2015, 11, e1005057.

(33) Harapanahalli, A. K.; Chen, Y.; Li, J.; Busscher, H. J.; van der Mei, H. C. Influence of Adhesion Force on icaA and cidA Gene Expression and Production of Matrix Components in Staphylococcus aureus Biofilms. Appl. Environ. Microbiol. 2015, 81, 3369-3378.

(34) Larmour, I. A.; Bell, S. E. J.; Saunders, G. C. Remarkably Simple Fabrication of Superhydrophobic Surfaces Using Electroless Galvanic Deposition. Angew. Chem. Int. Ed. 2007, 119, 1740-1742.

(35) Shirtcliffe, N. J.; McHale, G.; Newton, M. I.; Perry, C. C.; Pyatt, F. B. Plastron Properties of a Superhydrophobic Surface. Appl. Phys. Lett. 2006, 89, 104106.

(36) Manley, D. M. J. P., Change of Size of Air Bubbles in Water Containing a Small Dissolved Air Content. Brit. J. Appl. Phys. 1960, 11, 38-42.

(37) Peñas-López, P.; Parrales, M. A.; Rodríguez-Rodríguez, J. Dissolution of a Spherical Cap Bubble Adhered to a Flat Surface in Air-Saturated Water. J. Fluid Mech. 2015, 775, 53-76.

(38) Emami, B.; Bucher, T. M.; Tafreshi, H. V.; Pestov, D.; Gad-el-Hak, M.; Tepper, G. C. Simulation of Meniscus Stability in Superhydrophobic Granular Surfaces under Hydrostatic Pressures. Colloids Surf. A 2011, 385, 95-103.

(39) Flynn, M. R.; Bush, J. W. M. Underwater Breathing: the Echanics of Plastron Respiration. J. Fluid Mech. 2008, 608 .

(40) Rogers, K.; Kadner, R. J. Facts about E. coli: Dimensions, as Discussed in Bacteria: Diversity of Structure of Bacteria: - Britannica Online Encyclopedi. https://www.britannica.com/science/bacteria/Diversity-ofstructure-of-bacteria.

(41) Monteiro, J. M.; Fernandes, P. B.; Vaz, F.; Pereira, A. R.; Tavares, A. C.; Ferreira, M. T.; Pereira, P. M.; Veiga, H.; Kuru, E.; VanNieuwenhze, M. S.; Brun, Y. V.; Filipe, S. R.; Pinho, M. G. Cell Shape Dynamics During the Staphylococcal Cell Cycle. Nat. Commun. 2015, 6, 8055.

(42) Fadeeva, E.; Truong, V. K.; Stiesch, M.; Chichkov, B. N.; Crawford, R. J.; Wang, J.; Ivanova, E. P., Bacterial Retention on Superhydrophobic Titanium Surfaces Fabricated by Femtosecond Laser Ablation. Langmuir 2011, 27, 3012-3019.

(43) Truong, V. K.; Webb, H. K.; Fadeeva, E.; Chichkov, B. N.; Wu, A. H.; Lamb, R.; Wang, J. Y.; Crawford, R. J.; Ivanova, E. P. Air-Directed Attachment of Coccoid Bacteria to the Surface of Superhydrophobic Lotus-Like 
Titanium. Biofouling 2012, 28, 539-550.

(44) Arnott, J.; Wu, A. H.; Vucko, M. J.; Lamb, R. N. Marine Antifouling From Thin Air. Biofouling 2014, 30, 1045-1054.

(45) Henry, W. Experiments on the Quantity of Gases Absorbed by Water, at Different Temperatures, and under Different Pressures. Phil. Trans. R. Soc. LDN 1803, 93, 29-42+274-279.

(46) Hong, S.-J.; Li, Y.-F.; Hsiao, M.-J.; Sheng, Y.-J.; Tsao, H.-K. Anomalous Wetting on a Superhydrophobic Graphite Surface. Appl. Phys. Lett. 2012, 100, 121601.

(47) Fey, P. D.; Endres, J. L.; Yajjala, V. K.; Widhelm, T. J.; Boissy, R. J.; Bose, J. L.; Bayles, K. W. A Genetic Resource for Rapid and Comprehensive Phenotype Screening of Nonessential Staphylococcus aureus Genes. MBio. 2013, 4, e00537-12.

(48) Bayles, K. Product Information Sheet for NR-47222: Staphylococcus aureus subsp. aureus, Strain JE2, Transposon Mutant NE679 (SAUSA300_0629) BEI Resource, 2014. 


\section{Table Legends}

Table. 1. Water contact angle and surface roughness of glass slide, polyurethane (PU), white polystyrene sheet A (WPSA), white polystyrene sheet B (WPSB), and superhydrophobic surface (SHS)

\section{Figure Legends}

Figure 1. Comparison of bacterial attachment to a superhydrophobic surface (SHS), white polystyrene sheet A (WPSA), polyurethane (PU), white polystyrene sheet B (WPSB), and glass after $1 \mathrm{~h}$ exposure to a bacterial suspension: in (a) BHI broth and (b) PBS.

Figure 2. Total bacterial attachment ( $a$ and $b$ ) and surface coverage ( $c$ and d) on the superhydrophobic surface after 1, 4, 8, 16, and $24 \mathrm{~h}$ of exposure in BHI broth (a and c) and in PBS (b and d).

Figure 3. (a) Average WCA reduction of a superhydrophobic surface after 1, 4, 8, 16, and $24 \mathrm{~h}$ of bacterial exposure in BHI broth and PBS, and (b) WCA across the surface after the bacterial exposure

Figure 4. Comparison of bacterial attachment on a glass slide, polyurethane (PU), white polystyrene sheet A (WPSA), white polystyrene sheet B (WPSB), and a superhydrophobic surface (SHS) after $24 \mathrm{~h}$ of exposure to bacterial suspension: (a) in BHI broth and (b) in PBS, and correlation between the quantity of attached bacteria and surface roughness of samples: (c) in BHI broth, and (d) in PBS.

Figure 5. (a) Surface adhesion of $S$. aureus and S. aureus pbp 4 before and after disappearance of the air-bubble layer, (b) mirror like surface through the plastron effect of an air-bubble layer in DI water, and (c) disappearance of air-bubble layer between water and surface 


\begin{tabular}{ccc}
\hline Samples & Surface roughness $\left(\mathrm{R}_{\mathrm{a}}\right)$ & Water contact angle $\left(^{\circ}\right)$ \\
\hline Glass slide & $4.9 \pm 0.9 \mathrm{~nm}$ & $5.7 \pm 0.7^{\circ}$ \\
Polyurethane & $182.9 \pm 72.6 \mathrm{~nm}$ & $102 \pm 1.1^{\circ}$ \\
White polystyrene sheet A & $160.5 \pm 26.4 \mathrm{~nm}$ & $88.9 \pm 1.9^{\circ}$ \\
White polystyrene sheet B & $316.8 \pm 67.8 \mathrm{~nm}$ & $84.8 \pm 2.9^{\circ}$ \\
Superhydrophobic surface & $853.7 \pm 109.4 \mathrm{~nm}$ & $163.3 \pm 2.8^{\circ}$ \\
\hline
\end{tabular}

Table. 1. Water contact angle and surface roughness of glass slide, polyurethane (PU), white polystyrene sheet A (WPSA), white polystyrene sheet B (WPSB), and superhydrophobic surface (SHS) 


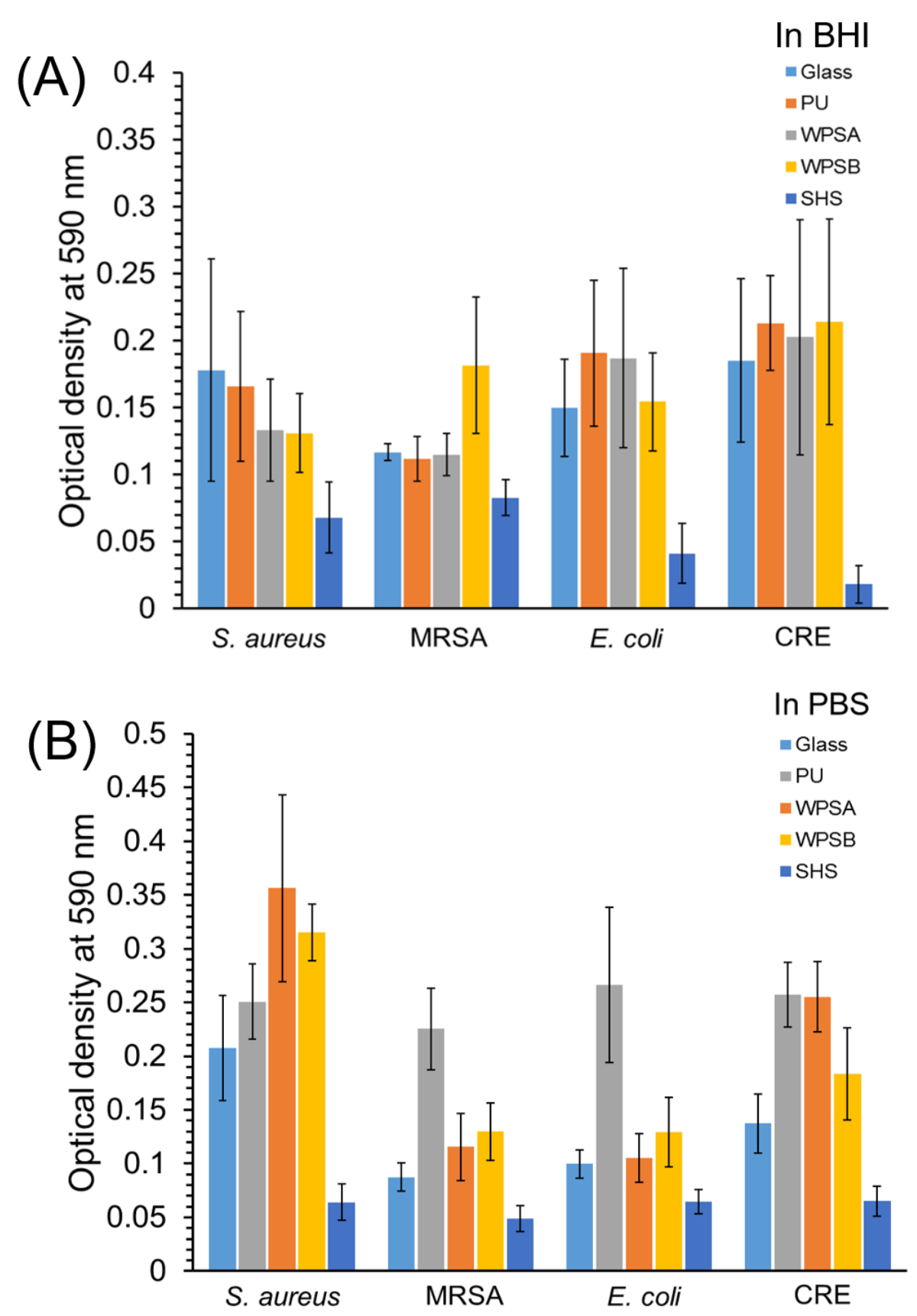

Figure 1. Comparison of bacterial attachment to a superhydrophobic surface (SHS), white polystyrene sheet A (WPSA), polyurethane (PU), white polystyrene sheet B (WPSB), and glass after $1 \mathrm{~h}$ exposure to a bacterial suspension: in (a) BHI broth and (b) PBS.

Staphylococcus aureus (S. aureus)

Escherichia coli (E. coli)

Methicillin-resistant Staphylococcus aureus (MRSA)

Carbapenem-nonsusceptible extended-spectrum $\beta$-lactamase producing strain of Escherichia coli (CRE) 

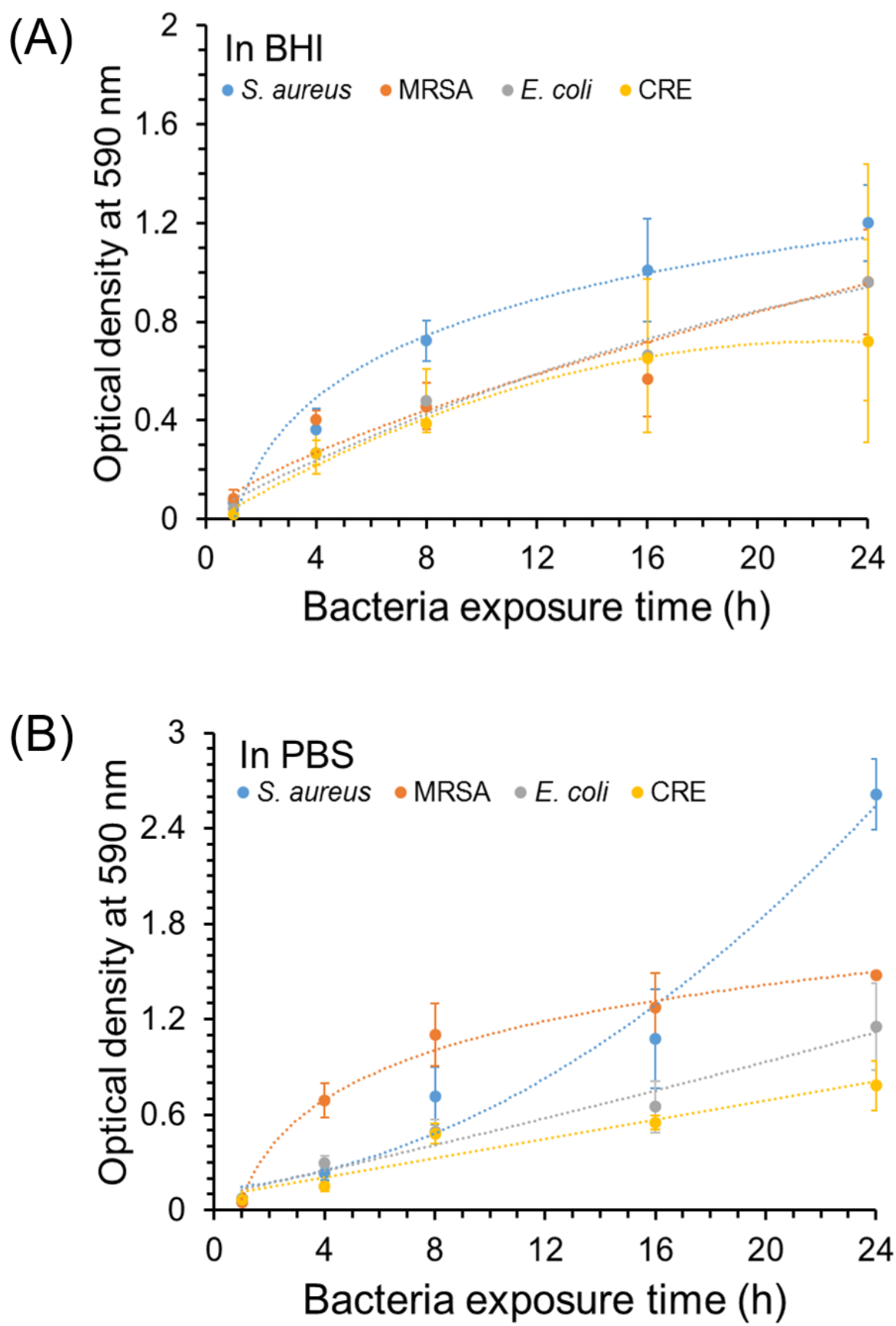

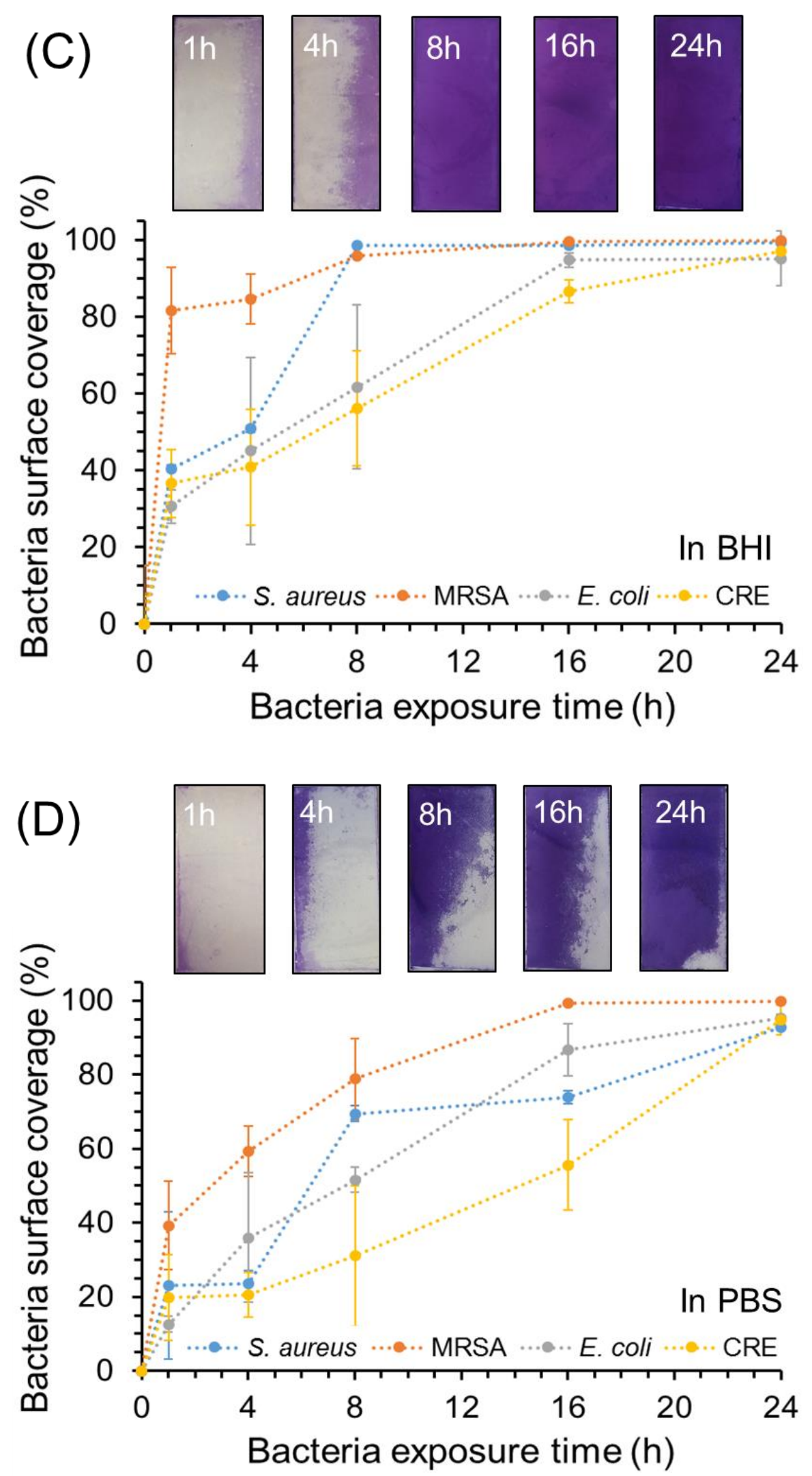

Figure 2. Total bacterial attachment $(\mathrm{a}$ and $\mathrm{b}$ ) and surface coverage (c and d) on the superhydrophobic surface after 1, 4, 8, 16, and $24 \mathrm{~h}$ of exposure in BHI broth (a and c) and in PBS (b and d). 
(A)

$180] \begin{aligned} & \text { In BHI } \\ & \text { O }\end{aligned}$
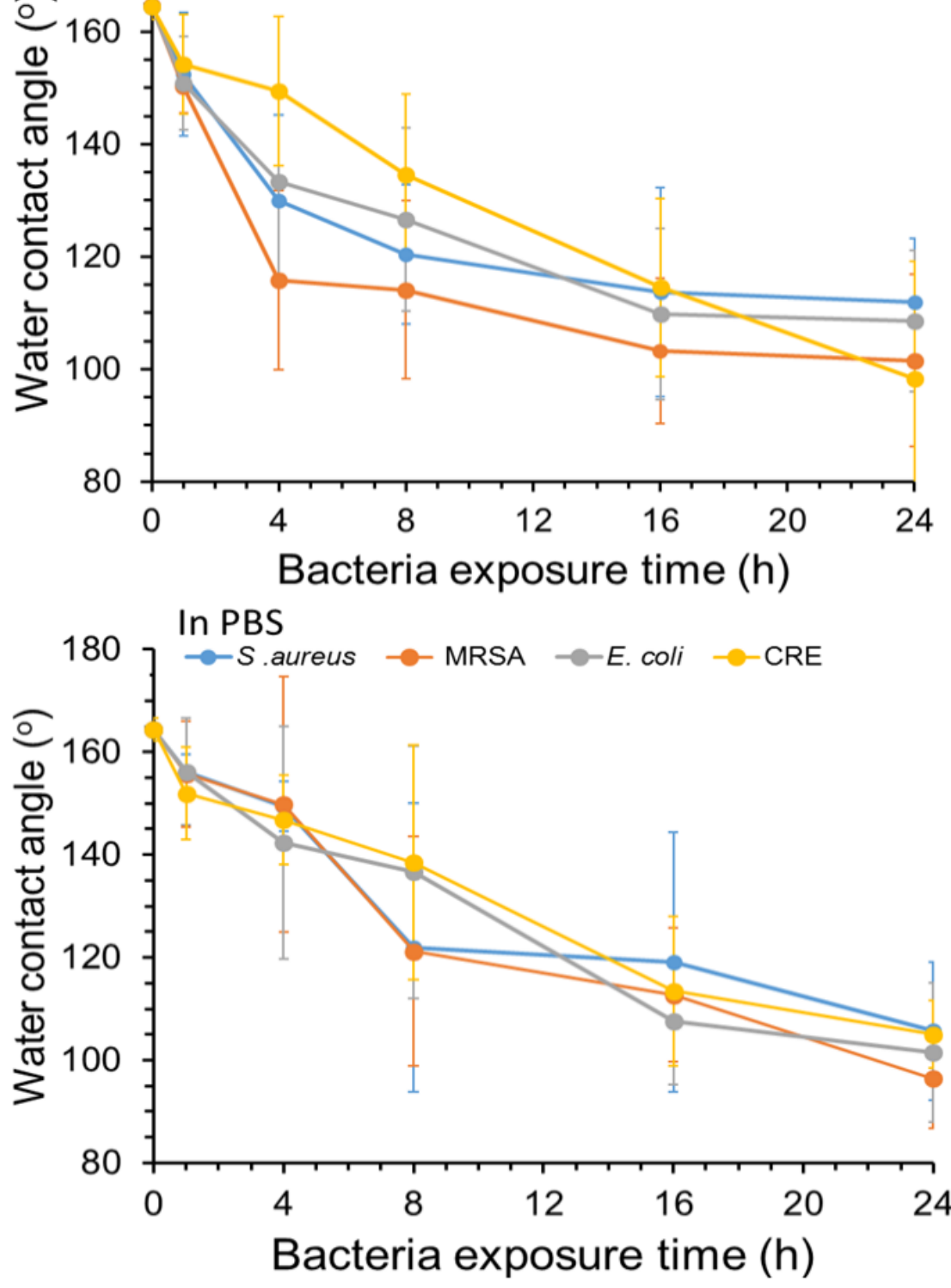


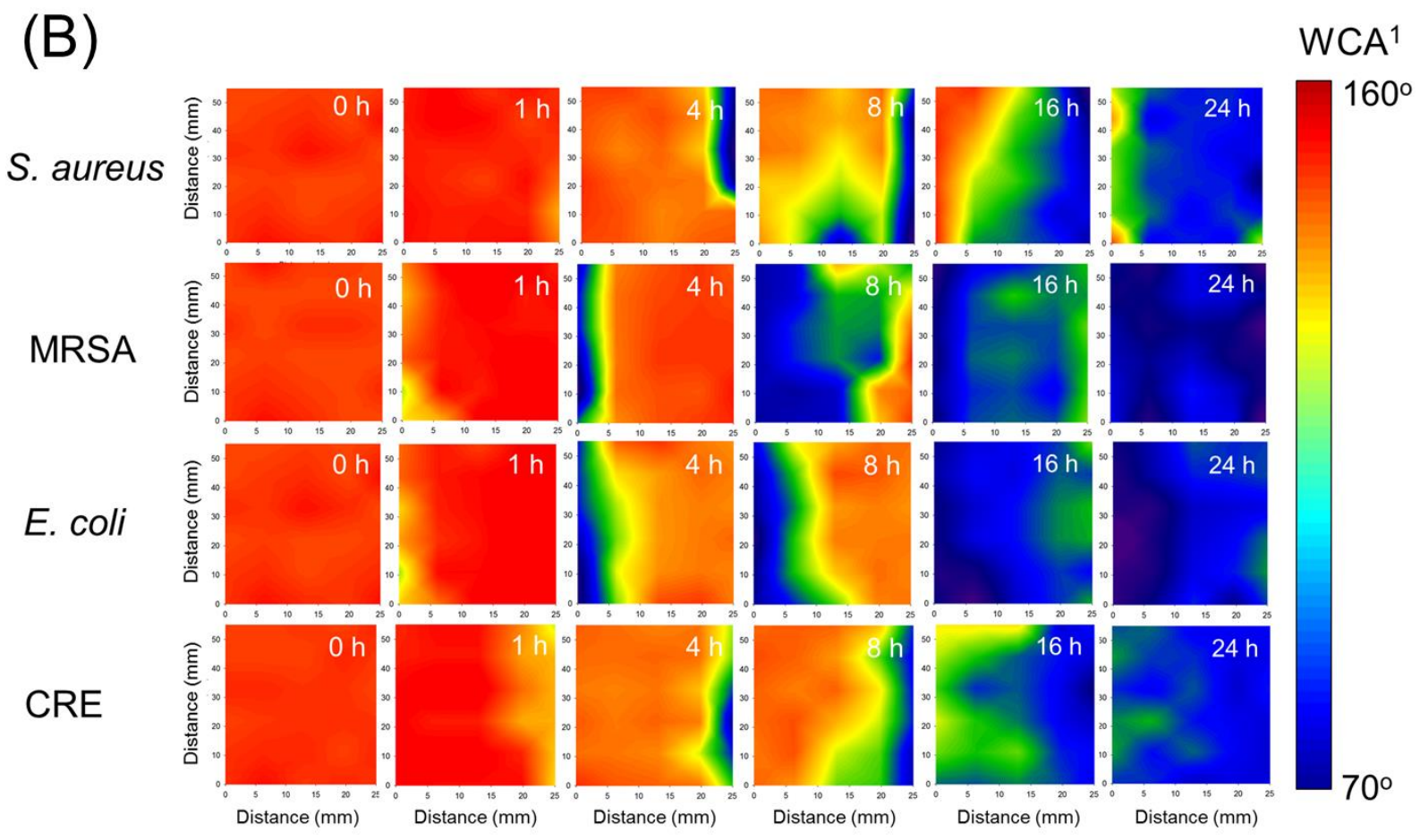

Figure 3. (a) Average WCA reduction of a superhydrophobic surface after 1, 4, 8, 16, and $24 \mathrm{~h}$ of bacterial exposure in BHI broth and PBS, and (b) WCA across the surface after the bacterial exposure

${ }^{1}$ WCA: water contact angle across superhydrophobic surface. 

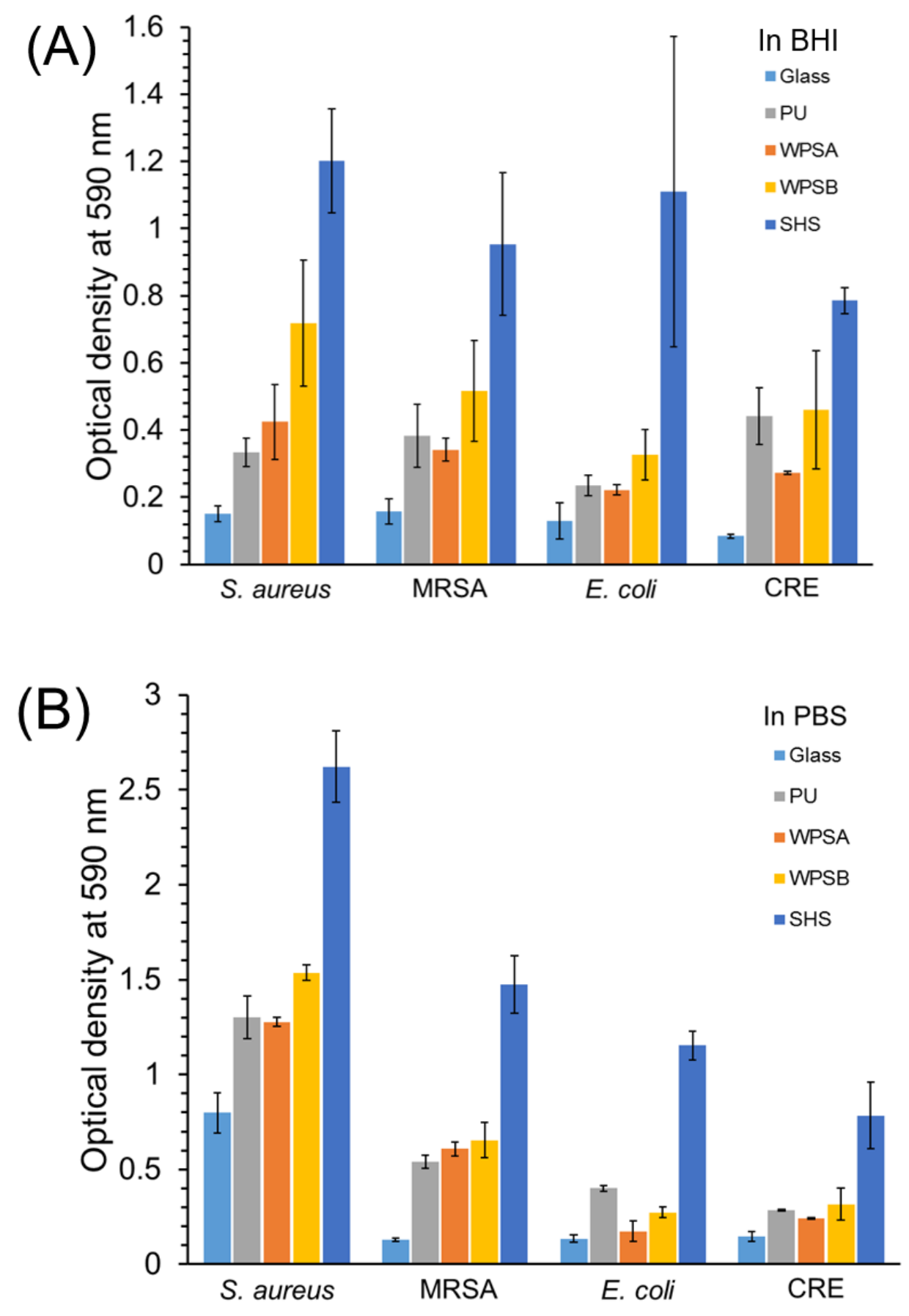

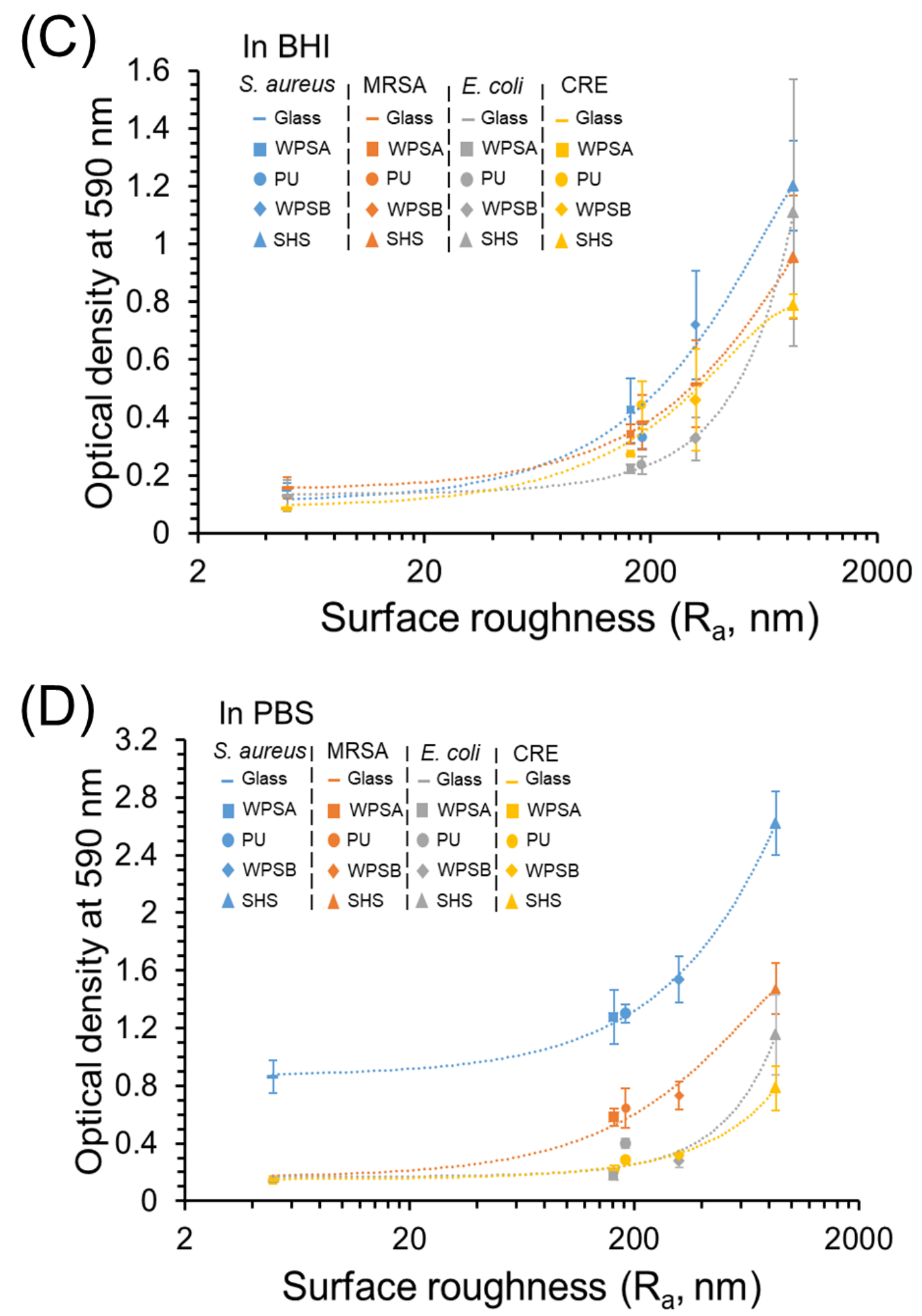

Figure 4. Comparison of bacterial attachment on a glass slide, polyurethane (PU), white polystyrene sheet A (WPSA), white polystyrene sheet B (WPSB), and a superhydrophobic surface (SHS) after $24 \mathrm{~h}$ of exposure to bacterial suspension: (a) in BHI broth and (b) in PBS, and correlation between the quantity of attached bacteria and surface roughness of samples: (c) in BHI broth, and (d) in PBS. 


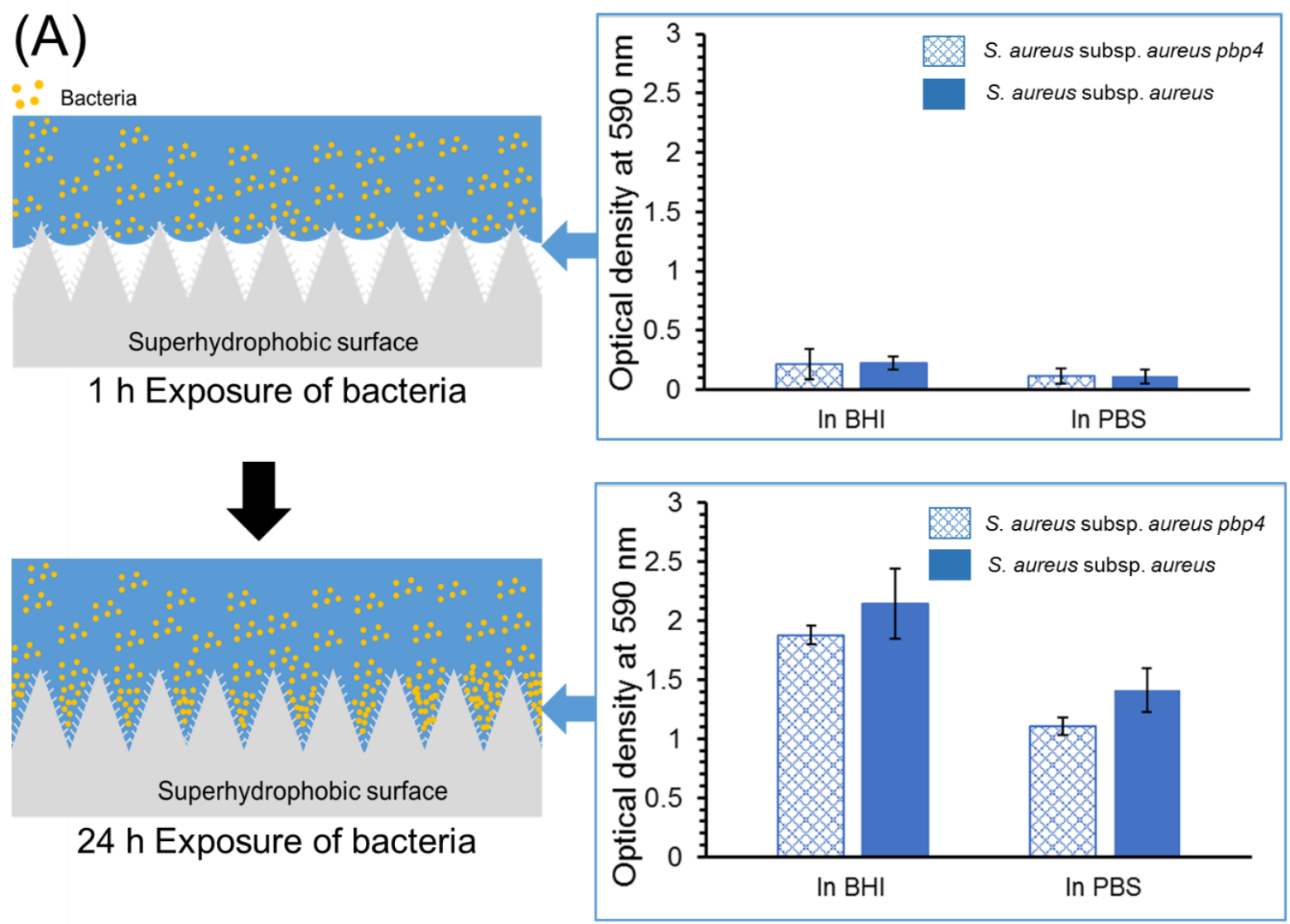

\section{(B)}
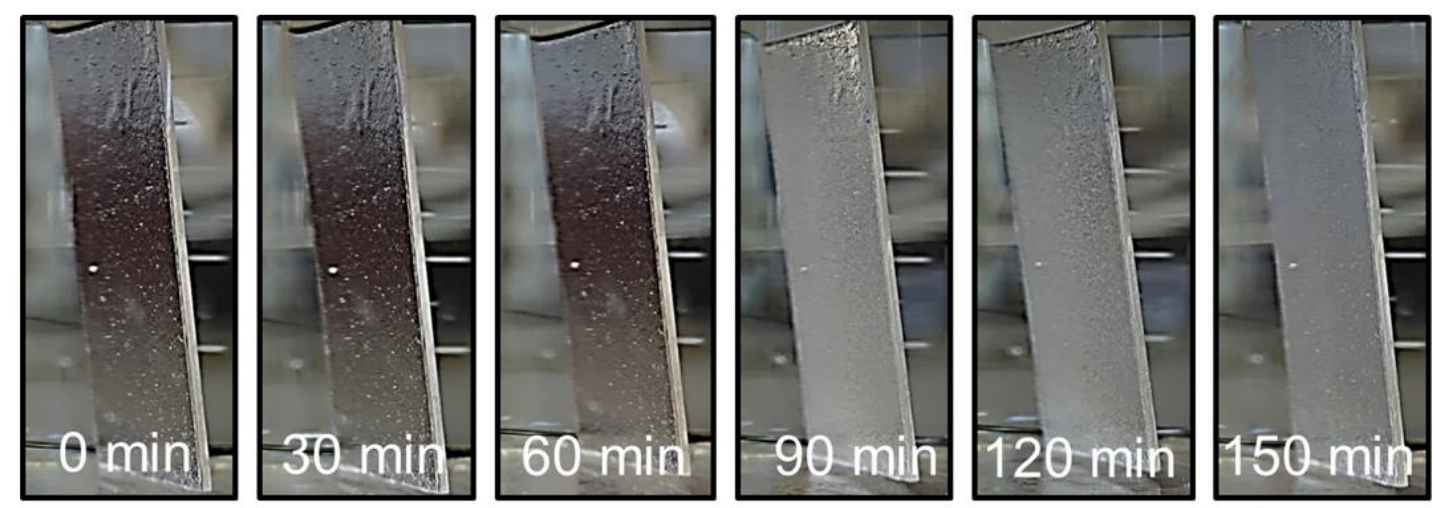

Elapsed time 


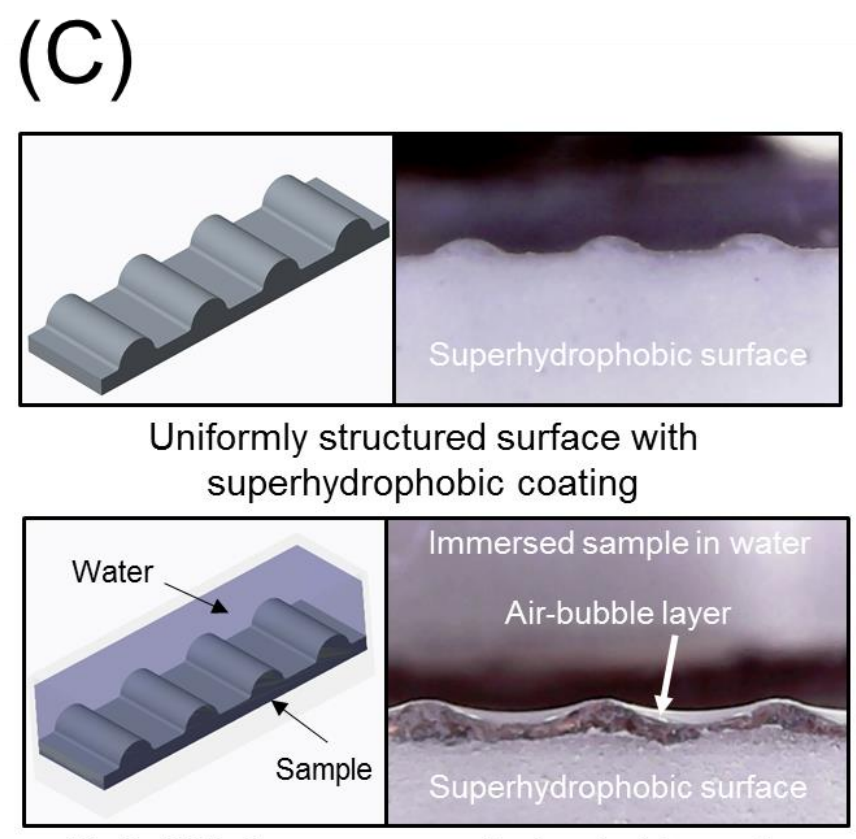

Air-bubble layer on superhydrophobic surface

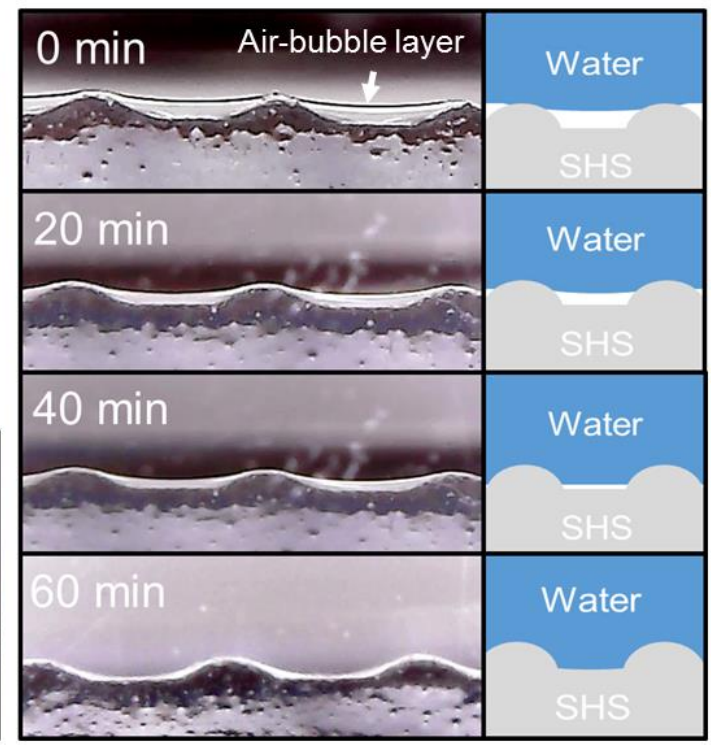

Disappearance of air-bubble layer

Figure 5. (a) Surface adhesion of $S$. aureus and S. aureus pbp 4 before and after disappearance of the air-bubble layer, (b) mirror like surface through the plastron effect of an air-bubble layer in DI water, and (c) disappearance of air-bubble layer between water and surface 


\section{Graphical Table of Contents}

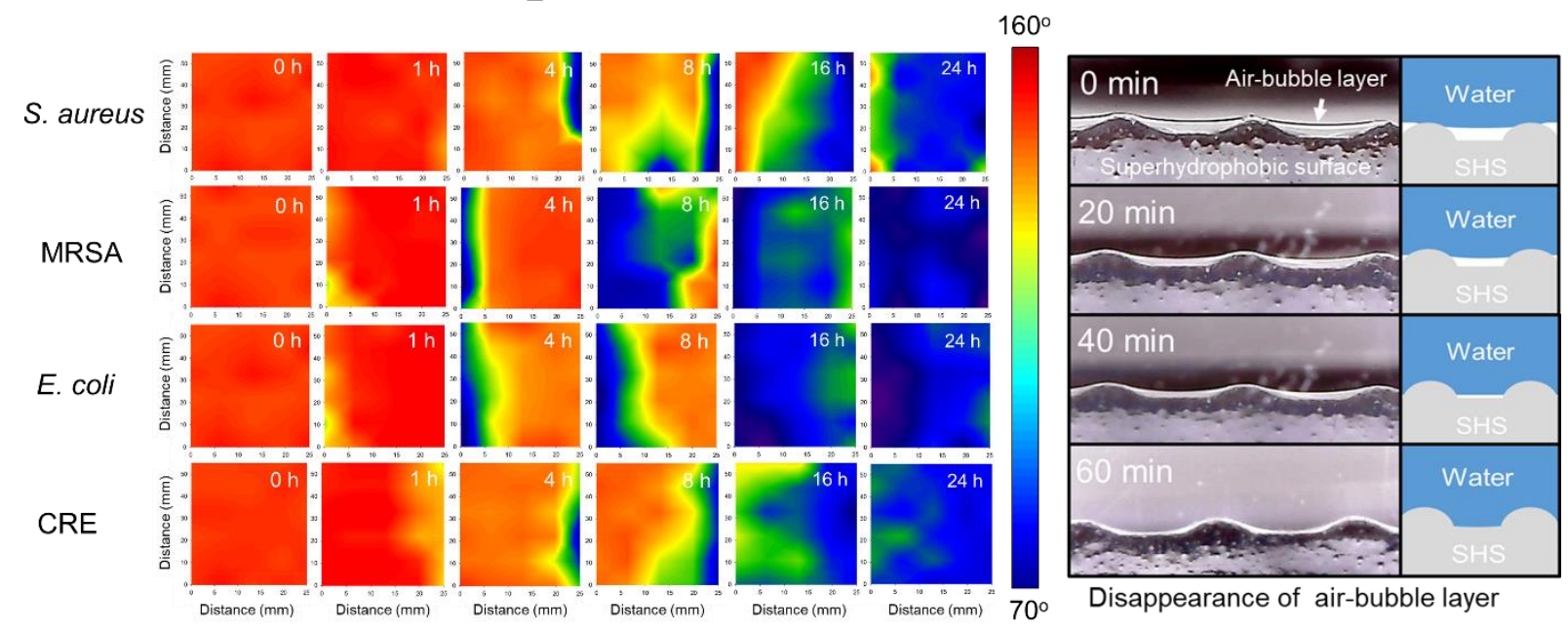

